\title{
ANALISIS KETAHANAN AIR DI KOTA TERNATE PROVINSI MALUKU UTARA
}

\author{
Prieta Firdayani Mulyono ${ }^{1}$, Haryono Putro ${ }^{2}$ \\ ${ }^{1}$ Mahasiswa Program Magister Teknik Sipil Universitas Gunadarma \\ 2 Dosen Jurusan Teknik Sipil Universitas Gunadarma \\ Korespondensi: prietafirdayani2@gmail.com
}

\begin{abstract}
Abstrak: Masalah terbesar di Kota Ternate adalah ketersediaan air dan juga potensi bencana alam, karena termasuk dalam Cincin Api Pasifik dan iklim di Kepulauan Maluku dipengaruhi oleh iklim tropis dan iklim musiman karena terdiri dari pulau-pulau dan dikelilingi oleh wilayah yang luas. Tujuan dari penelitian ini adalah menentukan ketahanan air di Kota Ternate untuk 20 tahun ke depan hingga 2039. Kebutuhan air dihitung dengan proyeksi metode eksponensial, data berdasarkan populasi, industri, ternak dan luas lahan pertanian. Data debit ketersediaan air didasarkan pada data infrastruktur sumber daya air yang telah tersedia di lokasi tersebut. Potensi ketersediaan yang dapat diandalkan dihitung menggunakan metode FJ Mock. Berdasarkan hasil analisis, diketahui bahwa total kebutuhan Kota Ternate pada tahun 2039 adalah 1,427 m3 / detik, total potensi debit andalan pada tahun 2039 adalah 43,139 m3 / detik dan total debit andalan yang dapat diandalkan adalah 0,700 m3 / detik, sehingga dapat disimpulkan bahwa permintaan air di Kota Ternate masih belum terpenuhi sepenuhnya, tetapi memiliki potensi besar untuk debit andalan. Sehingga perencanaan pembangunan infrastruktur diperlukan dalam bentuk sebanyak 98 buah waduk dengan total waduk 5,67 juta m3 / detik yang tersebar di lokasi DAS terbesar di beberapa daerah di Kota Ternate.
\end{abstract}

Kata Kunci : potensi debit andalan, embung, kebutuhan air, ketersediaan air, neraca air.

\begin{abstract}
The biggest problem in Ternate City is availability of water and potential for natural disasters, because it's in the fire ring and climate in there is influenced by the tropical and seasonal climate. The purpose of this study is determine the water resistance in Ternate City for $20^{\text {th }}$ years until 2039. Water requirements are calculated by exponential method projections, the data based on population, industry, livestock and the area of agricultural land. Water availability debit data is based on water resources infrastructure data that has been available in there. Based on the results of the analysis, known that the total requirement of Ternate City in 2039 is $1.427 \mathrm{~m}^{3} / \mathrm{sec}$, total potential of mainstay discharge in 2039 is $43.139 \mathrm{~m}^{3} / \mathrm{sec}$ and total potention of dependable flow is $0.700 \mathrm{~m}^{3} / \mathrm{sec}$, so it can be concluded that the water demand in there is still not fulfilled to its full potential but has a great potential for reliable debits. So that, infrastructure development planning is needed in the form of as many as 98 pieces of reservoirs with a total reservoir of 5.67 million $\mathrm{m}^{3} / \mathrm{sec}$ spread across the largest watershed locations in several areas in Ternate City.
\end{abstract}

Keywords : potention of dependable flow, retention basin, water demand, water avaibility, water balance.

Berdasarkan data Badan Meteorologi Klimatologi dan Geofisika, disimpulkan bahwa Kota Ternate memiliki curah hujan yang sangat rendah, rerata curah hujan $1500 \mathrm{~mm}$ per tahun. Berdasarkan data PDAM Kota Ternate yang dikutip dari situs berita online mongabay.com, diketahui bahwa sejak 2014 debit air di Kota Ternate mulai menurun dan mengalami ancaman krisis air. Hal tersebut disebabkan mata air Ake
Gaale Kelurahan Sangaji Ternate Utara yang berjarak kurang lebih 300 meter dari Pantai Sangaji terkena intrusi air laut, sehingga tidak hanya sumur PDAM yang terdampak, namun sumur warga juga terimbas. Sepanjang 2014 2016, debit air PDAM dari sumber Ake Gaale tidak dapat dikonsumsi dan warga di Ternate Utara menggunakan air payau. 
Berdasarkan data resiko bencana Badan Nasional Penanggulangan yang diolah oleh lokadata beritagar.id, diketahui bahwa Kota Ternate rawan erupsi Gunung Api Gamalama dan beresiko tinggi terhadap longsor, gempa bumi dan tsunami.

Berdasarkan studi ini, diharapkan dapat diketahui perbandingan besarnya debit kebutuhan air, debit ketersediaan infrastruktur sumber daya air dan potensi debit andalan di Kota Ternate sehingga dapat melakukan perencanaan progam pembangunan infrastruktur sumber daya air yang berfungsi untuk menampung potensi debit andalan yang berasal dari curah hujan di lokasi tersebut.

\section{METODOLOGI}

Proses Penelitian

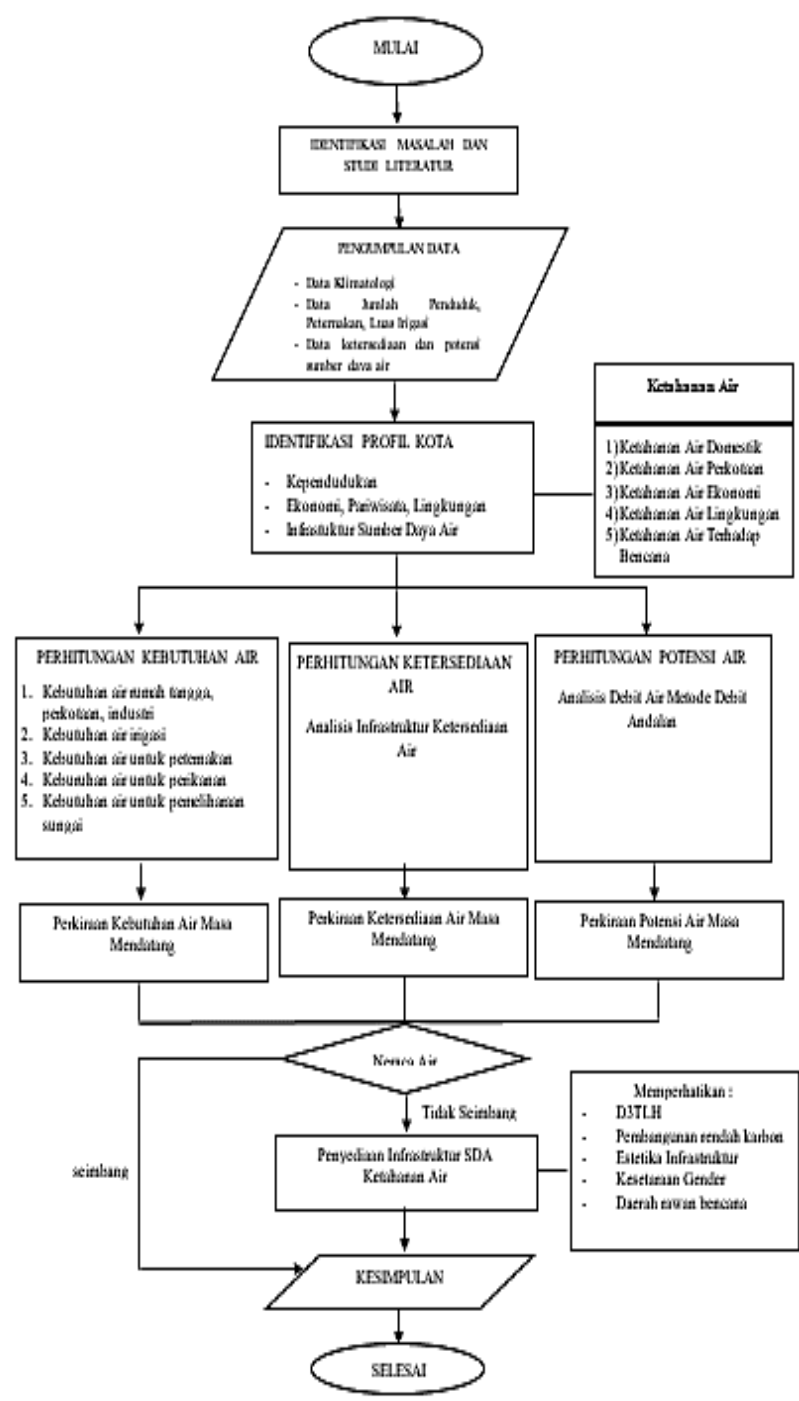

Gambar 1 Diagaram Alir Penelitian

Penelitian ketahanan air dimulai dari tahap studi literatur dan pengumpulan data yang meliputi data klimatologi, jumlah penduduk, jumlah peternakan, jumlah industri, luas areal irigasi, ketersediaan air, potensi sumber daya air. Tahapan penelitian yang diperlukan dalam teknik pelaksanaan penelitian ketahanan air sesuai dengan tujuan penelitian ini, untuk menghindari pekerjaan berulang.

\section{Data dan Teknik Pengumpulan Data}

Pada proses pengumpulan data, data yang digunakan adalah data sekunder . adapun data sekunder merupakan data yang diperoleh dari instansi - instansi pemerintah yang terkait dengan penelitian. Adapun data sekunder tersebut dapat dilihat pada Tabel 1 berikut.

Tabel 1 Jenis dan Sumber Data

\begin{tabular}{|c|c|}
\hline Jenis Data & Sumber Data \\
\hline $\begin{array}{l}\text { Peta Administrasi Kota } \\
\text { Ternate }\end{array}$ & $\begin{array}{l}\text { Bappeda Kota } \\
\text { Ternate }\end{array}$ \\
\hline Klimatologi & $\begin{array}{l}\text { BPS Kota Ternate; } \\
\text { Stasiun } \\
\text { Meteorologi } \\
\text { Babullah Ternate }\end{array}$ \\
\hline Jumlah Penduduk & BPS Kota Ternate \\
\hline Jumlah Peternakan & $\begin{array}{l}\text { BPS Kota Ternate; } \\
\text { Dinas Pertanian } \\
\text { Kota Ternate }\end{array}$ \\
\hline Jumlah Industri & $\begin{array}{l}\text { BPS Kota Ternate; } \\
\text { Dinas Perindustrian } \\
\text { dan Perdagangan } \\
\text { Kota Ternate } \\
\end{array}$ \\
\hline Luas Areal Irigasi & $\begin{array}{l}\text { BPS Kota Ternate; } \\
\text { Dinas Pertanian } \\
\text { Kota Ternate }\end{array}$ \\
\hline $\begin{array}{l}\text { Infrastruktur Ketersediaan } \\
\text { Air (danau, embung, } \\
\text { SPAM) }\end{array}$ & $\begin{array}{l}\text { Dinas Pekerjaan } \\
\text { Umum }\end{array}$ \\
\hline $\begin{array}{l}\text { Potensi Sumber Daya Air } \\
\text { (debit andalan) }\end{array}$ & BPS Kota Ternate \\
\hline
\end{tabular}

\section{ANALISA DAN PEMBAHASAN Profil Wilayah}

Secara astronomis, Kota Ternate terletak diantara $0^{0} 25^{\prime} 41,82^{\prime \prime}-1^{0} 21^{\prime} 21,78^{\prime \prime} \quad$ Lintang Utara dan antara $126^{\circ} 7^{\prime} 32,14^{\prime \prime}-127^{\circ} 26^{\prime} 23,12^{\prime \prime}$ Bujur Timur dan dilalui oleh garis ekuator atau garis khatulistiwa yang terletak pada garis lintang $0^{\circ}$. Sedangkan secara geografis Kota Ternate dibatasi oleh:
a. Utara : Laut Maluku
b. Selatan : Kota Tidore Kepulauan dan
Kabupaten Halmahera Selatan
c. Timur : Pulau Halmahera
d. Barat : Laut Maluku dan Pulau Sulawesi
Luas Kota Ternate adalah 5.709,58 $\mathrm{km}^{2}$, yang terdiri dari daratan $139,98 \mathrm{~km}^{2}$ dan lautan 
$5.569,60 \mathrm{~km}^{2}$. Kota Ternate merupakan kota kepulauan yang terdiri dari 3 pulau besar dan 5 pulau kecil. Ibukota Kota Ternate adalah Ternate Tengah dengan wilayah administratif terdiri dari 8 kecamatan dan 77 kelurahan.

\section{Proyeksi Kebutuhan Air Rumah Tangga dan Non Domestik}

Kebutuhan air bersih rumah tangga, dinyatakan dalam satuan Liter/Orang/Hari $(\mathrm{L} / \mathrm{O} / \mathrm{H})$, besar kebutuhan tergantung dari kategori kota berdasarkan jumlah penduduk dapat dilihat pada Tabel 2 berikut.

Tabel 2 Kebutuhan Air Bersih Rumah Tangga Menurut Kategori Kota

\begin{tabular}{|l|l|l|c|}
\hline No & Kategori Kota & $\begin{array}{c}\text { Jumlah Penduduk } \\
\text { (jiwa) }\end{array}$ & $\begin{array}{c}\text { Kebutuhan } \\
\text { Air Bersih } \\
\text { (L/O/H) }\end{array}$ \\
\hline 1 & $\begin{array}{l}\text { Semi urban } \\
\text { (ibu kota } \\
\text { kecamatan/ } \\
\text { desa) }\end{array}$ & $3.000-20.000$ & $60-90$ \\
\hline 2 & Kota kecil & $20.000-100.000$ & $90-110$ \\
\hline 3 & Kota sedang & $100.000-500.000$ & $100-125$ \\
\hline 4 & Kota besar & $500.000-1.000 .000$ & $120-150$ \\
\hline 5 & Metropolitan & $>1.000 .000$ & $150-200$ \\
\hline
\end{tabular}

Sumber: SNI 6728.1-2015

Hasil perhitungan proyeksi kebutuhan air rumah tangga dan non domestik dari tahun 2017 hingga tahun 2039 mengalami peningkatan dari tahun ke tahun. Proyeksi total kebutuhan air rumah tangga dan non domestik tahun 2039 adalah sebesar $0,787 \mathrm{~m}^{3} /$ detik. Rincian kebutuhan air rumah tangga dan domestik dapat dilihat pada Gambar 2 berikut.

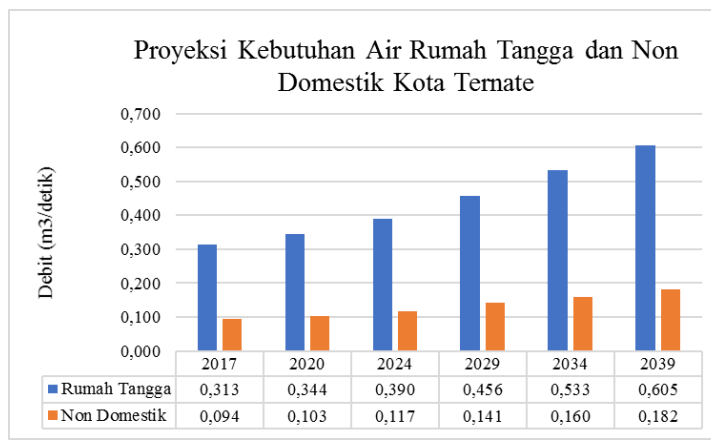

Gambar 2 Proyeksi Kebutuhan Air Rumah Tangga dan Non Domestik Kota Ternate Sumber: Hasil Analisis, 2018

\section{Proyeksi Kebutuhan Air Industri}

Perhitungan kebutuhan air industri berdasarkan standar yang telah ditetapkan oleh
Direktorat Jenderal Cipta Karya (1994) sebagai berikut:

a. Industri besar membutuhkan air sebesar $0,50-1,00$ liter/detik/ha

b. Industri sedang membutuhkan air sebesar $0,25-0,50$ liter/detik/ha

c. Industri kecil membutuhkan air sebesar $0,15-0,25$ liter/detik/ha

Berdasarkan Gambar 3, diketahui bahwa kebutuhan air industri mengalami peningkatan yang signifikan setiap tahunnya. Pada tahun 2039, proyeksi total kebutuhan air industri adalah sebesar $0,25 \mathrm{~m}^{3} /$ detik.

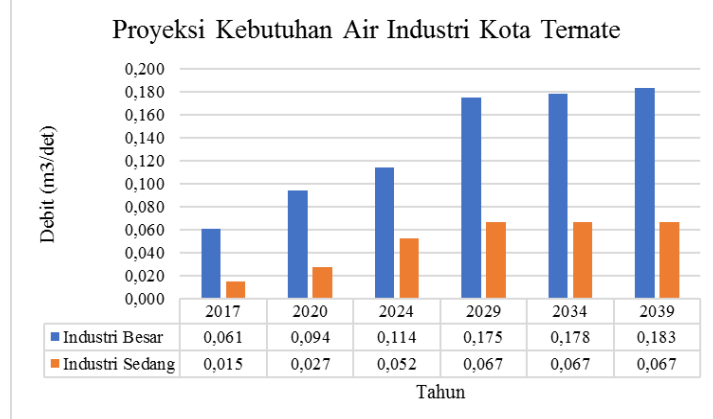

Gambar 3 Proyeksi Kebutuhan Air Industri Kota Ternate

Sumber: Hasil Analisis, 2018

\section{Proyeksi Kebutuhan Air Ternak dan Unggas}

Besar kebutuhan air hewan ternak dapat dilihat pada Tabel 3 berikut.

Tabel 3 Kebutuhan Air Ternak

\begin{tabular}{|c|c|}
\hline Jenis Ternak & $\begin{array}{c}\text { Kebutuhan Air } \\
\text { (1/ekor/hari) }\end{array}$ \\
\hline Sapi/kerbau/kuda & 40 \\
\hline Kambing/domba & 5 \\
\hline Babi & 6 \\
\hline Unggas & 0,6 \\
\hline
\end{tabular}

Sumber: SNI 6728.1-2015

Kebutuhan air ternak didominasi oleh unggas dan hewan ternak besar yang terdiri dari sapi/kerbau/kuda. Total proyeksi kebutuhan air ternak tahun 2039 adalah sebesar 0,0468 $\mathrm{m}^{3} /$ detik.

Rincian kebutuhan air ternak dan unggas dari tahun 2017 hingga tahun 2039 dapat dilihat pada Gambar 4. 


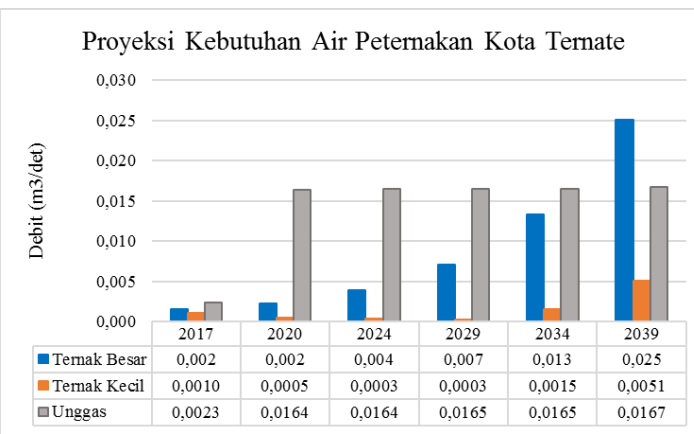

Gambar 4 Proyeksi Kebutuhan Air Hewan

Ternak dan Unggas Kota Ternate Sumber: Hasil Analisis, 2018

\section{Proyeksi Kebutuhan Air Pertanian}

Kota Ternate tidak mempunyai area persawahan dan sebagian besar lahannya digunakan untuk menanam tumbuhan holtikultura dan rempah-rempah, sehingga kebutuhan air yang dihitung hanya kebutuhan air tanaman holtikultura.

Kebutuhan air pertanian bidang holtikultura di Kota Ternate meningkat setiap tahunnya. Hal ini dapat dilihat pada Gambar 5 yaitu proyeksi kebutuhan air pada tahun 2017 sebesar $0,74 \mathrm{~m}^{3} /$ detik dan pada tahun 2039 adalah sebesar $1,40 \mathrm{~m}^{3} /$ detik.

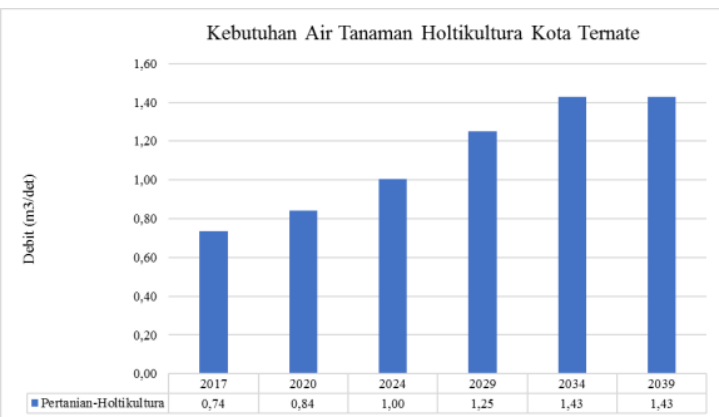

Gambar 5 Proyeksi Kebutuhan Air Tanaman Holtikultura Kota Ternate Sumber: Hasil Analisis, 2018

\section{Analisis Infrastruktur Ketersediaan Air}

Terdapat 2 danau di kota Ternate yang dapat dimanfaatkan oleh masyarakat dengan total debit $0,23 \mathrm{~m}^{3} /$ detik, yaitu danau Laguna (Ngade) dan danau Tolire. Tabel 4 berikut merupakan rincian volume air di 2 (dua) danau tersebut.

Tabel 4 Danau di Kota Ternate

\begin{tabular}{|l|l|c|c|c|r|}
\hline No & $\begin{array}{c}\text { Nama } \\
\text { Danau }\end{array}$ & $\begin{array}{c}\text { Luas } \\
(\mathbf{m} 2)\end{array}$ & $\begin{array}{c}\text { Kedalaman } \\
(\mathbf{m})\end{array}$ & $\begin{array}{c}\text { Volume } \\
\left(\mathbf{m}^{\mathbf{3}}\right)\end{array}$ & $\begin{array}{c}\text { Volume } \\
\left(\mathbf{m}^{\mathbf{3}} / \mathbf{d e t}\right)\end{array}$ \\
\hline 1 & $\begin{array}{l}\text { Laguna } \\
\text { (Ngade) }\end{array}$ & 182.200 & $1-35,5$ & 2.924 .635 & 0,093 \\
\hline 2 & Tolire & 50.000 & 50 & 4.300 .000 & 0,0136 \\
\hline \multicolumn{2}{|c}{ Total } & 232.200 & 50 & 7.224 .635 & 0,229 \\
\hline
\end{tabular}

Sumber: Sensus Penduduk 2010 dan Potensi Desa 2014; BPS Kota Ternate, 2018
Selain danau, terdapat beberapa Sistem Penyediaan Air Minum (SPAM) di Kota Ternate dengan total kapasitas $0,215 \mathrm{~m}^{3} /$ detik. Adapun rincian SPAM dan kapasitasnya dapat dilihat pada Tabel 5 berikut.

Tabel 5 SPAM Kota Ternate

\begin{tabular}{|l|l|r|}
\hline No & \multicolumn{1}{|c|}{ SPAM } & \multicolumn{1}{c|}{ Kapasitas } \\
\hline 1 & SPAM P. Hiri, Kota Ternate & L/detik \\
\hline 2 & SPAM Kota Ternate & $100 \mathrm{~L} /$ detik \\
\hline 3 & $\begin{array}{l}\text { Jaringan Distribusi Utama } \\
\text { Kota Ternate }\end{array}$ & $5 \mathrm{~L} /$ detik \\
\hline 4 & $\begin{array}{l}\text { SPAM Kawasan Kumuh Kota } \\
\text { Ternate }\end{array}$ & $5 \mathrm{~L} /$ detik \\
\hline 5 & $\begin{array}{l}\text { SPAM Kampus Universitas } \\
\text { Khairun Ternate }\end{array}$ & $215 \mathrm{~L} /$ detik \\
\hline \multicolumn{2}{|c|}{ Jumlah } & $0,215 \mathrm{~m}^{3} /$ detik \\
\hline
\end{tabular}

Sumber: E-monitoring Pelaksanaan Anggaran Provinsi Maluku Utara

\section{Analisis Potensi Sumber Daya Air}

Potensi sumber daya air di Kota Ternate berasal dari air hujan yang merupakan sumber air baku utama bagi masyarakat dan lingkungan. Berdasarkan hasil perhitungan menggunakan metode FJ Mock, diperoleh hasil total debit andalan adalah $43,139 \mathrm{~m}^{3} /$ detik.

\section{Analisis Potensi Sumber Daya Air}

Berdasarkan hasil perhitungan dapat diketahui proyeksi total kebutuhan air pada tahun 2039 sebesar $1,607 \mathrm{~m}^{3} /$ detik, potensi sumber daya air sebesar $43,13 \mathrm{~m}^{3} /$ detik dan ketersediaan air sebesar $0,700 \mathrm{~m}^{3} /$ detik. Rekapitulasi kebutuhan air, ketersediaan air terpasang dan potensi sumber daya air Tabel 6 berikut.

Tabel 6 Rekapitulasi Perhitungan

\begin{tabular}{|l|c|c|c|c|c|c|}
\hline \multirow{2}{*}{$\begin{array}{l}\text { Kebutuhan Air } \\
\left(\mathrm{m}^{3} / \text { detik }\right)\end{array}$} & \multicolumn{6}{|c|}{ Tahun } \\
\cline { 2 - 7 } $\begin{array}{l}\text { Rumah } \\
\text { Tangga }\end{array}$ & 0,323 & 0,344 & 0,390 & 0,456 & 0,533 & 0,605 \\
\hline Non Domestik & 0,094 & 0,103 & 0,117 & 0,137 & 0,160 & 0,182 \\
\hline Industri & 0,076 & 0,076 & 0,076 & 0,076 & 0,076 & 0,076 \\
\hline Peternakan & 0,039 & 0,019 & 0,021 & 0,024 & 0,031 & 0,047 \\
\hline $\begin{array}{l}\text { Pertanian- } \\
\text { Holtikultura }\end{array}$ & 0,737 & 0,841 & 1,003 & 1,250 & 1,427 & 1,427 \\
\hline $\begin{array}{l}\text { Total } \\
\text { Kebutuhan } \\
\text { Air }\end{array}$ & 1,269 & 1,384 & 1,436 & 1,491 & 1,547 & 1,607 \\
\hline Potensi Air & 43,13 & 43,13 & 43,13 & 43,19 & 43,13 & 43,13 \\
\hline $\begin{array}{l}\text { Ketersediaan } \\
\text { Air }\end{array}$ & 0,005 & 0,700 & 0,700 & 0,700 & 0,700 & 0,700 \\
\hline
\end{tabular}

Sumber: Hasil Analisis, 2018

Berdasarkan hasil analisis, diketahui bahwa potensi air di Kota Ternate masih dapat memenuhi kebutuhan air hingga tahun 2039. Namun ketersediaan infrastruktur bangunan air yang terpasang atau tersedia di kota tersebut belum dapat memenuhi kebutuhan air yang ada, sehingga perlu dilakukan program pembangunan 
infrastruktur bangunan air untuk menampung air hujan.

\section{Perencanaan Program Pembangunan}

Perencanaan pembangunan infrastruktur dibuat dalam bentuk program pembangunan dengan periode 5 tahunan dalam jangka waktu 20 tahun hingga tahun 2039, pembagian periode tersebut berdasarkan Sistem Perencanaan Pembangunan Nasional yaitu satu kesatuan tata cara perencanaan pembangunan untuk menghasilkan rencana-rencana pembangunan dalam jangka panjang, jangka menengah, dan tahunan yang dilaksanakan oleh unsur penyelenggara negara dan masyarakat di tingkat Pusat dan Daerah. Tabel 7a dan Tabel 7b berikut adalah rencana program pemenuhan kebutuhan air di Kota Ternate per periode.

Tabel 7a Rencana Program Kebutuhan Air Kota Ternate Periode 2020 - 2024 dan $2025-2029$

\begin{tabular}{|c|c|c|c|c|c|c|}
\hline \multirow[b]{2}{*}{$\begin{array}{c}\text { Periode } \\
\text { Pem- } \\
\text { bangunan }\end{array}$} & \multicolumn{3}{|c|}{$2020-2024$} & \multicolumn{3}{|c|}{$2025-2029$} \\
\hline & $\begin{array}{l}\text { Proyeksi } \\
\text { Keb. Air }\end{array}$ & $\begin{array}{c}\text { Target } \\
\text { Pemen } \\
\text { uhan }\end{array}$ & $\begin{array}{l}\text { Debit } \\
\text { Program } \\
\text { Infr }\end{array}$ & $\begin{array}{l}\text { Proyeksi } \\
\text { Keb. Air }\end{array}$ & $\begin{array}{l}\text { Target } \\
\text { Peme } \\
\text { nuhan }\end{array}$ & $\begin{array}{l}\text { Debit } \\
\text { Program } \\
\text { Infr. }\end{array}$ \\
\hline & $\mathrm{m}^{3} /$ detik & $\%$ & $\mathrm{~m}^{3} /$ detik & $\mathrm{m}^{3} /$ detik & $\%$ & $\mathrm{~m}^{3} /$ detik \\
\hline $\begin{array}{l}\text { Keb. Air } \\
\text { RKI } \\
\end{array}$ & 0,583 & $80 \%$ & 0,466 & 0,669 & $100 \%$ & 0,669 \\
\hline $\begin{array}{l}\text { Keb. Air } \\
\text { Peternakan }\end{array}$ & 0,021 & $80 \%$ & 0,016 & 0,024 & $100 \%$ & 0,024 \\
\hline $\begin{array}{l}\text { Keb. Air } \\
\text { Perkebunan }\end{array}$ & 1,003 & $60 \%$ & 0,602 & 1,250 & $70 \%$ & 0,875 \\
\hline $\begin{array}{l}\text { Total } \\
\text { Keb.Air }\end{array}$ & 1,607 & & 1,085 & 1,085 & & 1,568 \\
\hline $\begin{array}{l}\text { Program } \\
\text { Pembangun } \\
\text { an }\end{array}$ & & & 1,080 & & & 0,483 \\
\hline
\end{tabular}

Sumber: Hasil Analisis, 2018

Tabel 7b Rencana Program Kebutuhan Air Kota Ternate Periode 2030 - 2034 dan $2035-2039$

\begin{tabular}{|l|r|r|r|r|r|c|}
\hline \multirow{2}{*}{$\begin{array}{c}\text { Periode } \\
\text { Pem- } \\
\text { bangunan }\end{array}$} & $\begin{array}{c}\text { Proyeksi } \\
\text { Keb. Air }\end{array}$ & $\begin{array}{c}\text { Target } \\
\text { Pemen } \\
\text { uhan }\end{array}$ & $\begin{array}{c}\text { Debit } \\
\text { Program } \\
\text { Infr }\end{array}$ & $\begin{array}{c}\text { Proyeksi } \\
\text { Keb. Air }\end{array}$ & $\begin{array}{c}\text { Target } \\
\text { Peme } \\
\text { nuhan }\end{array}$ & $\begin{array}{c}\text { Debit } \\
\text { Program } \\
\text { Infr. }\end{array}$ \\
\hline $\mathrm{m}^{3} /$ detik & $\%$ & $\mathrm{~m}^{3} /$ detik & $\mathrm{m}^{3} /$ detik & $\%$ & $\mathrm{~m}^{3} /$ detik \\
\hline $\begin{array}{l}\text { Keb. Air } \\
\text { RKI }\end{array}$ & 0,769 & $100 \%$ & 0,769 & 0,863 & $100 \%$ & 0,863 \\
\hline $\begin{array}{l}\text { Keb. Air } \\
\text { Peternakan }\end{array}$ & 0,031 & $100 \%$ & 0,031 & 0,047 & $100 \%$ & 0,047 \\
\hline $\begin{array}{l}\text { Keb. Air } \\
\text { Perkebunan }\end{array}$ & 1,427 & $80 \%$ & 1,141 & 1,427 & $90 \%$ & 1,284 \\
\hline $\begin{array}{l}\text { Total } \\
\text { Keb.Air }\end{array}$ & 2,227 & & 1,942 & 2,337 & & 2,914 \\
\hline $\begin{array}{l}\text { Program } \\
\text { Pembangun } \\
\text { an }\end{array}$ & & 0,374 & & & 0,252 \\
\hline
\end{tabular}

Sumber: Hasil Analisis, 2018

Metode yang digunakan untuk menghitung kapasitas suatu tampungan salah satunya yaitu metode Ripple. Total kapasitas tampungan dari keempat periode tersebut yaitu 5,67 juta $\mathrm{m}^{3}$. Untuk memenuhi kebutuhan air di Kota Ternate maka diperlukan pembangungan infrastruktur SDA berupa embung yang tersebar di setiap kecamatan. Hal ini dikarenakan kondisi geografi dan topografi di wilayah tersebut. Tabel 8 berikut merupakan jumlah dan luas embung pada masing-masing periode.

Tabel 8 Jumlah dan Luas Embung di Kota Ternate

\begin{tabular}{|l|l|c|c|}
\hline \multicolumn{1}{|c|}{ Kecamatan } & \multicolumn{1}{|c|}{ Nama DAS } & $\begin{array}{c}\text { Luas } \\
(\mathrm{Ha})\end{array}$ & $\begin{array}{c}\text { Jml } \\
\text { Embung }\end{array}$ \\
\hline P. Ternate & DAS Kastela & 2 & 10 \\
\hline P. Moti & DAS Hiri & 7 & 10 \\
\hline P. Batang Dua & & & 14 \\
\hline P. Hiri & DAS Dabaang & 5 & 4 \\
\hline Ternate Selatan & DAS Serabu & 6 & 4 \\
\hline Ternate Tengah & $\begin{array}{l}\text { DAS } \\
\text { Marikurubu }\end{array}$ & 1 & 4 \\
\hline Ternate Utara & DAS Togurara & 1 & 4 \\
\hline
\end{tabular}

Sumber: Hasil Analisis, 2018

Lokasi dari DAS pada Tabel 8 dapat dilihat pada Gambar 6 berikut.

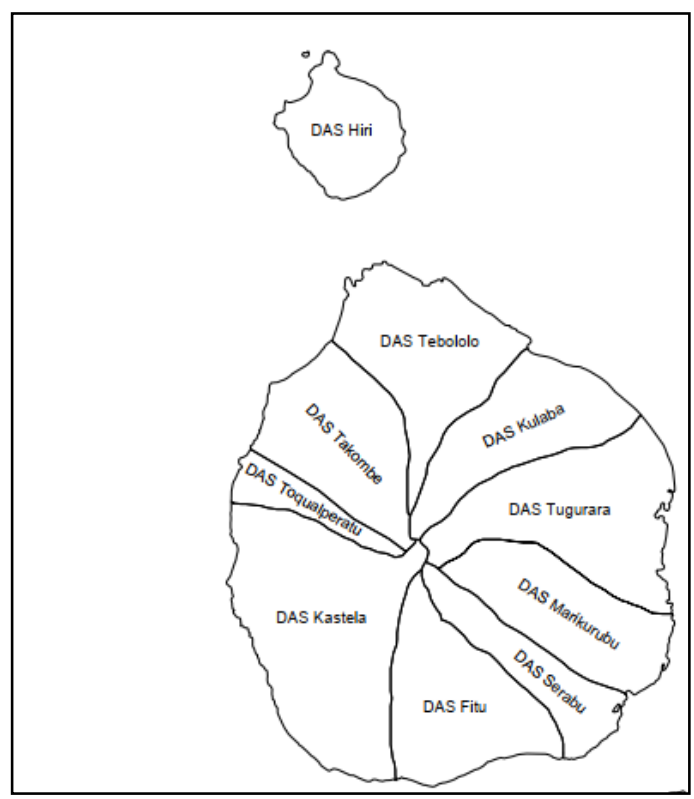

Gambar 6 Lokasi DAS Kota Ternate

Sumber: Hasil Analisis, 2018

\section{KESIMPULAN}

Berdasarkan analisis yang telah dilakukan, terdapat beberapa hal yang menjadi kesimpulan diantaranya adalah sebagai berikut:

1. Kebutuhan Air di Kota Ternate pada tahun 2039 adalah $1,427 \mathrm{~m}^{3} /$ detik.

2. Total potensi debit andalan di Kota Ternate pada tahun 2039 adalah 43,139 $\mathrm{m}^{3} /$ detik yang berasal dari curah hujan di wilayah tersebut.

3. Total debit ketersediaan air di Kota Ternate pada tahun 2039 adalah $0,700 \mathrm{~m}^{3} /$ detik yang terdiri dari SPAM dan air danau di wilayah tersebut.

4. Kebutuhan air di Kota Ternate masih belum terpenuhi secara maksimal. Namun Kota Ternate memiliki potensi debit andalan yang besar yaitu $43,139 \mathrm{~m}^{3} /$ detik, sehingga diperlukan suatu rencana pembangunan 
infrastruktur untuk menampung air hujan tersebut.

5. Perencanaan pembangunan infrastruktur adalah berupa pembangunan embung sebanyak 98 buah dengan total kapasitas tampungan 5,67 juta $\mathrm{m}^{3} /$ detik yang tersebar di lokasi DAS terbesar di beberapa wilayah di Kota Ternate.

\section{UCAPAN TERIMA KASIH}

Ucapan terima kasih penulis persembahkan kepada orang tua beserta kedua adik yang telah memberikan dukungan dan do'a kepada penulis selama melakukan penelitian ini. Terima kasih pula kepada teman-teman Teknik Sipil 2013-A Universitas Gunadarma dan dosen Jurusan Teknik Sipil atas bimbingan dan ilmu yang diberikan selama perkuliahan.

\section{DAFTAR PUSTAKA}

Badan Standardisasi Indonesia, Penyusunan Neraca Spasial Sumber Daya Alam -
Bagian 1: Sumber Daya Air, SNI 6728.1:2015, $2015: 2$

Badan Pusat Statistik. 2010. Pedoman Perhitungan Proyeksi Penduduk dan Angkatan Kerja. Jakarta: Badan Pusat Statistik.

Badan Pusat Statistik. 2017. Kota Ternate Dalam Angka 2017. Jakarta: Badan Pusat Statistik.

Dumairy, Ekonomika Sumber Daya Air: Pengantar ke Hidrodinamika, Jogjakarta, 1992

Kementerian Pekerjaan Umum, Panduan Pengintegrasian Aspek Gender Dalam Perencanaan Program dan Anggaran Kementerian Pekerjaan Umum, Jakarta, 2009 : 2

Badan Nasional Penanggulangan Bencana, Pedoman Penyusunan Rencana Penanggulangan Bencana, Perkep BNPB No 4 Tahun 2008, Jakarta, $2008: 5$ 